\title{
The Arctic Ocean-a Canadian perspective from IPY
}

\author{
H. Melling • R. Francois $•$ P. G. Myers $•$ W. Perrie • \\ A. Rochon $\cdot$ R. L. Taylor
}

Received: 12 April 2012 / Accepted: 13 August 2012

(C) Crown Copyright (Canada) 2012

\begin{abstract}
Canada's IPY program funded seven marine projects spanning the North American Arctic. Work embraced oceanography, air-sea interactions, storm response, paleoclimate and trace-element chemistry. Notable findings are emerging. Conditions in the Beaufort were unusual in 2007, with very high air pressure bringing strong winds, rapid ice drift, thin winter ice, enhanced shelf-break upwelling and a maximum in freshwater retention in the Beaufort Gyre. A mapping of trace chemicals suggests that Arctic mid-depth circulation may also have reversed. Study of Canadian Arctic through-flow revealed a net annual seawater export of 44,000 cubic kilometres from the Arctic to Baffin Bay. Observations of sea ice, sustained through the IPY, affirmed that ice cover is the key attribute of Arctic seas, with wind as a potent agent in its variation. Surveys have shown that the anthropogenic decline in seawater alkalinity is aggravated in the Arctic by low temperature and low salinity resulting from ice melt. Careful experiments have revealed that Arctic phytoplankton growth is constrained by scarcity of dissolved iron where light levels are low. A manganese fingerprint in sediments has tracked changing sea level during the Ice Age.
\end{abstract}

Electronic supplementary material The online version of this article (doi:10.1007/s10584-012-0576-4) contains supplementary material, which is available to authorized users.

H. Melling $(\bowtie)$

Fisheries and Oceans Canada, Institute of Ocean Sciences, PO Box 6000, Sidney, BC, Canada V8L 4B2 e-mail: Humfrey.Melling@dfo-mpo.gc.ca

R. Francois $\cdot$ R. L. Taylor

Department of Earth and Ocean Sciences, University of British Columbia, Vancouver, BC, Canada V6T $1 \mathrm{Z4}$

P. G. Myers

Department Earth and Atmospheric Sciences, University of Alberta, Edmonton, AB, Canada T6G 2E3

W. Perrie

Fisheries and Oceans Canada, Bedford Institute of Oceanography, 1 Challenger Drive, Dartmouth, NS, Canada B2Y 4A2

A. Rochon

Institut des sciences de la mer de Rimouski (ISMER), Université du Québec à Rimouski, Rimouski, QC, Canada G5L 3A1 
Sediment-core analysis has revealed the Arctic Oscillation as a dominant cause of longperiod climate variations during the Holocene. One project has demonstrated how multitasked vessels can maintain a watch on Canada's Arctic within a reliable affordable logistic framework, while a wave forecast model developed by another for the Beaufort is suitable for operational use.

\section{The ice-covered ocean is the keystone of the Arctic}

The core of the Arctic is a deep ocean. Whereas maritime regions at lower latitude have climates distinctive for their moderation, the Arctic is different. Here the ocean's capacity for buffering climate by exchanging heat and moisture with the atmosphere is dramatically reduced by its ice cap. Sea ice inhibits transfers of vapour and heat to the atmosphere in the cold months, creating the Arctic's cold, dry continental-style winter. Its high reflectivity and latent heat reduce the ocean's absorption of sunshine, and slow ice melting until insolation is much reduced, thereby contributing to the Arctic's cool and cloudy summers.

Whereas land at the South Pole allows only the atmosphere to carry environmental influences to the highest Antarctic latitudes, the ocean is an active participant in the Arctic. Here both atmospheric and oceanic exchanges mediate strong influences on the Arctic's ice, ocean and ecosystem from the Pacific to Atlantic Oceans.

The general circulation of the atmosphere results from pressure gradients that reflect differences in air temperature between the equator and the poles. The general circulation of the ocean is driven in part by that of the atmosphere (i.e., wind) and in part by pressure gradients that reflect differences in salinity as well as temperature of seawater. Since the salinity effect dominates at Arctic temperatures, freshwater is important there.

The world-wide variation of salinity reflects the hydrologic cycle. Moisture evaporates predominantly in the tropics, where temperature is highest, and inexorably migrates to high latitude because low temperature inhibits evaporation. In the Pacific, the mountains of western North America stand up against prevailing winds and trap freshwater within the basin, thereby raising sea level about $40 \mathrm{~cm}$ above the Beaufort and $80 \mathrm{~cm}$ above the Atlantic (Conkright et al. 2002). Pacific surface water flows down this staircase through Bering Strait, across the Arctic and on to the Atlantic. The Arctic outflow is augmented by freshwater from Arctic precipitation to north-flowing rivers.

The climate of the Arctic has been warming for decades. Simultaneous oceanic changes include a warmer inflow to the Arctic from the Atlantic (Schauer et al. 2008) to sporadic warming of the Pacific inflow (Woodgate et al. 2010). Changes in Arctic hydrography include warming seawater at mid depths (Polyakov et al. 2005; Dmitrenko et al. 2010), increased freshwater storage in the Canada Basin (Polyakov et al. 2008; Rabe et al. 2011), concentration of this storage near America and a broader transpolar drift towards the Atlantic (Rigor et al. 2002). Changes in the ocean and atmosphere have coincided with decline in Arctic ice extent (Kwok et al. 2009).

Freshwater is ultimately delivered to the Atlantic via movements of diluted seawater and sea ice across the Canadian polar shelf (domain of the Canadian Arctic Archipelago) and through Fram Strait. Computer models demonstrate that changes in the rate and path of Arctic outflow can influence the Atlantic overturning circulation (MOC) by changing the vertical density gradient in the Labrador, Irminger and Greenland Seas (Vellinga et al. 2008).

Engagement of the Arctic Ocean in the climate system is diverse and far-reaching. The Canadian program for the International Polar Year (IPY) was planned to contribute constructively to the larger international effort. Canadian efforts were not intended to deliver 
independently in terms of scope or geography. However, IPY in Canada was linked with other countries' activities to advance Arctic marine science and move it closer to societal relevance, public policy and applications.

This paper describes Canadian Arctic marine science during the IPY. The paper is organized so that Canadian contributions appear as building blocks within a conceptual framework of the climate system, as defined by the headings that follow. With this approach, the paper demonstrates how Canadian work has advanced the prolonged international thrust to understand the Arctic Ocean and climate.

\section{Canadian Arctic marine projects for the IPY}

The Canadian Programme for the $4^{\text {th }}$ International Polar Year included seven components focused on physical and chemical aspects of the marine environment, named by the headings that follow. Figure 1 shows the approximate geographic domain of each project.

\subsection{Canada's three oceans (C3O)}

The motivating premise of $\mathrm{C} 3 \mathrm{O}$ was the dynamical, chemical and biological connectedness of Canada's three oceans: understanding of the Arctic depends upon understanding adjacent domains in the Pacific and Atlantic. This project used scheduled Arctic patrols by Canada's Coast Guard from Victoria to Halifax as opportunities for scientific observations, linked physical, chemical and biological snapshots of the ocean along a 13,000 km path encircling Canada. Voyages in 2007 and 2008 demonstrated the viability of multi-tasked voyages of discovery and yielded a baseline for future monitoring of Canada's oceans.

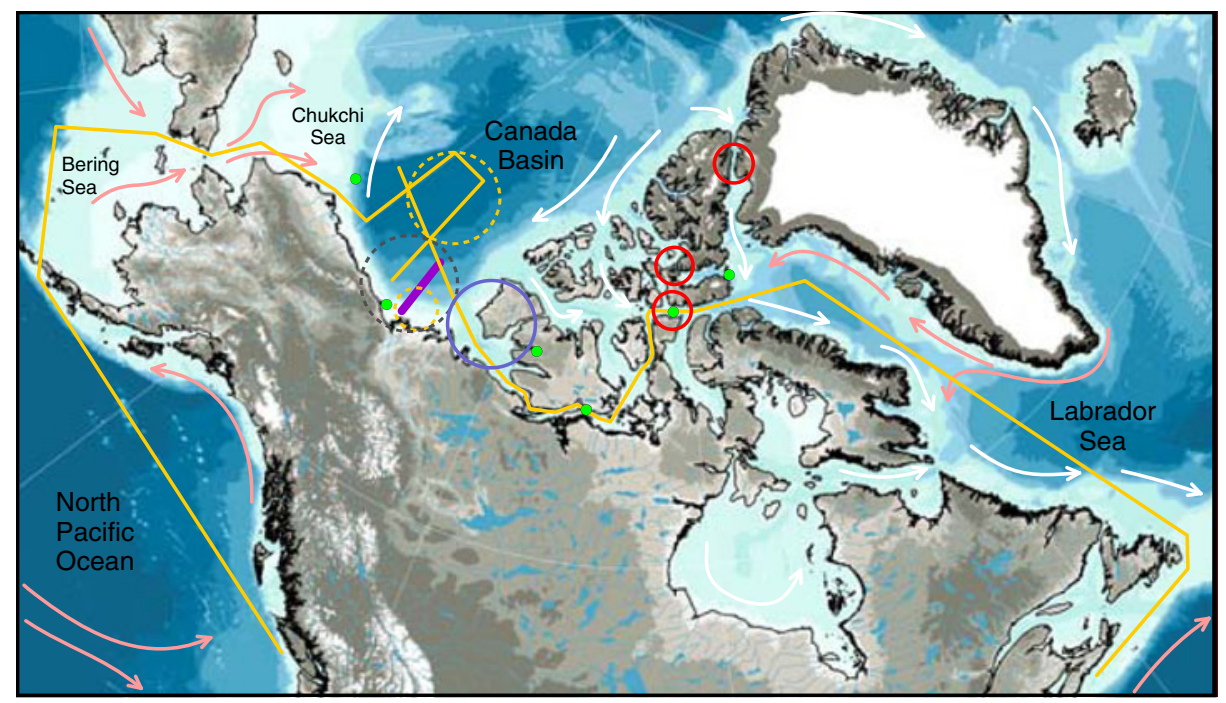

Fig. 1 Canada's three oceans and the locations of IPY-Canada research activities. C3O section (yellow line), C3O observatories (yellow circles), CAT installations (red circles), GEOTRACES (purple line), CFL (blue circle), Beaufort storms (black circle), paleo-coring (green dots). Ocean surface currents are delineated by arrows: pink for warm, white for cold 


\subsection{Ocean currents of Arctic Canada (CATs)}

C3O's descriptive ocean study was complemented during IPY by the Arctic Sub-Arctic Ocean Fluxes (ASOF: http://asof.npolar.no/ ) study to measure and model water movement between them. Although continents allow flow between oceans via only a few pathwaysBering Strait, Canadian polar shelf, Fram Strait, Barents shelf-it was nonetheless necessary to link several countries' efforts for IPY. The responsibility of the Canadian Arctic Throughflow study (CATs) was the Canadian polar shelf, with goals embracing comprehensive observation of Canadian Arctic through-flow and understanding its drivers and its role in the climate system.

\subsection{Climate change impacts on nutrient and carbon cycles in the Arctic Ocean}

Tracers are chemicals at low concentration in seawater whose presence and transformations provide useful insights into ocean contaminants, ecology, circulation, geochemistry and climate. This project, part of the GEOTRACES global study (http://www.geotraces.org/), surveyed tracers in the Arctic Ocean, studied their sensitivity to physical and ecological factors and analyzed their functions. Elements for study included micronutrient metals (e.g., iron, copper); isotopes of carbon, nitrogen and silica that record biological cycles; radiogenic isotopes that tag water masses; radioactive isotopes that provide flux estimates.

\subsection{Severe Arctic storms and climate change in coastal areas}

Dramatic recent changes in Arctic coastal weather and sea conditions have affected coastal ecosystems and the safety and livelihood of seaside communities. This project's goal was study of the interaction between severe weather and marine hazards in the Beaufort and of the synergy among ice extent, storm winds, waves, currents and surges that create them. One planned output was a Beaufort wind climatology, identifying weather patterns that bring extreme winds and storm surges to the coast. Others were evaluated computer models for forecasting wind-wave-surge hazards in the area and for simulating their impact via coastal flooding and erosion.

\subsection{The circumpolar flaw lead system study (CFL)}

A flaw lead is an intermittent exposure of the sea surface at the pack-ice margin in winter. It is a focus for new ice production, ridging, enhanced mixing and upwelling and is habitat for light-seeking and air-breathing life. The CFL study examined ocean dynamics, carbon and nutrient cycles, contaminants and the ecosystem of the Beaufort flaw lead. CCGS Amundsen supported CFL's field study for 293 days in 2007-2008, while traditional knowledge was explored in a study of Inuvialuit's use of sea ice.

\subsection{Natural climate variability in the Canadian Arctic}

Climate of the past provides context for studies of its present state. This project examined aquatic sediments for evidence of Arctic climate variation during the last million years. Cores from Baffin Bay, the North West Passage to the Beaufort Sea were studied. The recent paleoclimate of the Arctic was inferred from interpretations of foraminiferal assemblages, ice-rafted debris and isotopic signatures linked to summertime sea-surface temperature and sea ice. 
2.7 The carbon cycle in the Canadian Arctic and subArctic continental margin

Carbon is essential to life. In the ocean, it is most vigourously utilized by organisms within shallow shelf seas. Since continental shelf underlies more than half the Arctic Ocean, understanding the physical and biogeochemical cycling of carbon on the shelves is tantamount to understanding Arctic marine carbon. In this project, shallow sediment cores were collected at the margins of the Arctic basins and chemically analyzed to construct a 40,000-year history of carbon in Canada's three oceans.

\section{Arctic Ocean waters originate in the Pacific, the Atlantic and the atmosphere}

Seawater inflows to the Arctic from the Atlantic to Pacific oceans have been reviewed most recently by Beszczynska-Möller et al. (2011). The Atlantic inflow originates in the eastern North Atlantic and moves through the European sector, via Fram Strait and the Barents Sea. With such remote entry points, Atlantic inflow was not a focus of Canadian study during IPY. However, the source and pathway of Pacific inflow via Bering Strait were studied during C3O's circum-navigation of Canada during IPY; Fig. 1 shows the section in 2008); Carmack et al. (2010) provide a companion figure for 2007.

The Pacific inflow responds to the high stand of sea level in the North Pacific. The combined inflow of rivers from the mountainous West Coast forms a low salinity current whose buoyancy drives it north-west following the shoreline to the Bering Sea (Royer 1998). The C3O transect twice crossed this "river in the ocean", at the start west of Vancouver Island, and again at the Aleutian Islands, where the Alaskan Stream and the Alaska Coastal Current (Weingartner et al. 2005b) merge (Fig. 2: 0, $3500 \mathrm{~km}$ ). Much of the current passes through the Aleutians and continues along the eastern side of the Bering Sea (Woodgate et al. 2006). The $\mathrm{C} 3 \mathrm{O}$ transect encounters this low salinity stream twice also, south of Bering Strait and again on the northern Chukchi Shelf (Fig. 2: 4000, $5000 \mathrm{~km}$ ).

Freshwater inflow via Bering Strait is about $1 / 3$ of the total delivery to the Arctic; the rest comes roughly equally from rivers and from precipitation-less-evaporation (Lewis et al. 2000). The Pacific inflow also carries an abundance of dissolved nutrients essential to primary production. Concentrations of dissolved nutrients were low during the $\mathrm{C} 3 \mathrm{O}$ transects through the Bering-Chukchi because these occurred in late July, after the rapid biological uptake of nutrients during spring bloom. During winter's darkness, however, the inflow carries nutrients undepleted into the Arctic halocline (Cooper et al. 1997).

Inflow via Bering Strait and its strong influence on the environment and ecology of the Arctic are influenced by large year-to-year variations in wind and precipitation in the Pacific sector (Woodgate et al. 2006). The $\mathrm{C} 3 \mathrm{O}$ project demonstrated that a meaningful watch on this variability and its impacts can be maintained with modest resources using ships of opportunity that travel this route.

Fresh waters originating in the Pacific, in the Atlantic and in Arctic rivers can be distinguished via chemical signatures. For example, Pacific water has a distinctive neodymium signature imparted by the weathering of volcanic rocks that comprise the Pacific Rim (Goldstein and Hemming 2004); such rock is enriched in ${ }^{143} \mathrm{Nd}$ via the radioactive decay of ${ }^{147} \mathrm{Sm}$, which is itself enriched in the mantle where the magma originates. The high ${ }^{143} \mathrm{Nd} /{ }^{144} \mathrm{Nd}$ ratio in Pacific water differs from those of Atlantic and river waters, which contact old continental crust. 

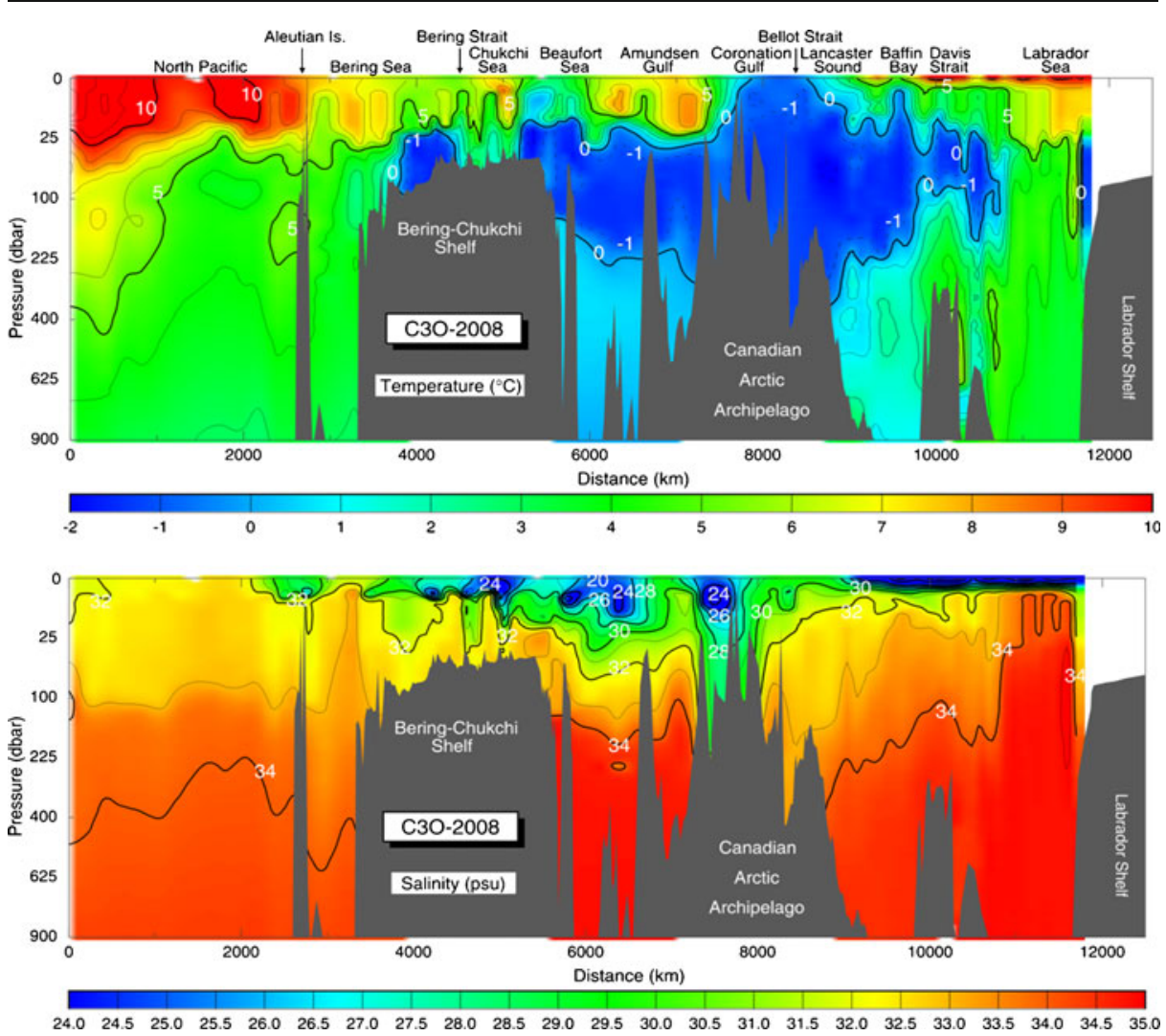

Fig. 2 The C3O section of seawater temperature (top); and salinity (bottom); measured in July 2008. The section follows the track plotted schematically in Fig. 1

Samples for analysis were collected during the IPY-GEOTRACES program in the southern Beaufort Sea. The high measured ratio of neodymium isotopes reveals a presence of Pacific freshwater even at great depth in the Canada Basin (Porcelli et al. 2009). Low salinity water from the Pacific can only reach such depth if its salinity is greatly enhanced via extreme ice growth, likely in flaw leads near the coast. The IPY study of neodymium therefore provides a new means to trace rare ventilation of the Arctic basins by Pacific water.

Another dissolved metal, barium, is a tracer of river water in the upper $300 \mathrm{~m}$ of the Arctic Ocean. The concentration of dissolved barium in freshwater released by melting sea ice, about $5 \mathrm{nmol} / \mathrm{kg}$, is much lower than that in freshwater from the Mackenzie River $(520 \mathrm{nmol} / \mathrm{kg})$. The concentration of dissolved barium in seawater therefore readily reveals the fractions of melted ice and river water in seawater (Guay and Falkner 1998). In 2007 the barium concentration was low, indicating that melted ice was the principal cause of surface freshening at the southern margin of the Beaufort Gyre that year. Samples from 2009 have more barium, indicative of greater river influence. The lack of river water in the area in 2007 reflects the unusually strong anti-cyclonic wind regime in the southern Beaufort during the first half of IPY (see Supplementary Figure 1). 


\section{The Arctic Ocean stores water and ice for varying intervals}

On reaching the Arctic Ocean at Point Barrow the $\mathrm{C} 3 \mathrm{O}$ section made a 1600-km detour through the southern Canada Basin, reaching $74^{\circ} \mathrm{N}$ and a depth of $3500 \mathrm{~m}$ before returning to the Canadian polar shelf at Amundsen Gulf (Fig. 1).

The anticyclonic Beaufort Gyre is the cause of deepened isohalines near $6500 \mathrm{~km}$ in Fig. 2. It is a vast reservoir of freshwater (Proshutinsky et al. 2009); until recently it has been capped year-round by thick sea ice.

The top 30-50 $\mathrm{m}$ of the Gyre cycles between an isohaline freezing condition in winter and a melt-water stratified warmer state in summer, when the $\mathrm{C} 3 \mathrm{O}$ section was measured. A cool halocline conditioned by intruding Pacific inflow lies between the seasonally active layer and a warm core (250-1000 m) of water from the Atlantic (McLaughlin et al. 1996). A cold saline bottom layer underlies the section.

The cool character of the halocline is maintained mainly by two types of intruding Pacific water, conditioned by summer and winter conditions on the Bering and Chukchi shelves (Coachman and Barnes 1961). Summer inflow has lower salinity and contributes a relatively shallow $(60-100 \mathrm{~m})$ warm layer with high oxygen and low nutrients. Winter inflow is more saline and colder from involvement in ice growth; it arrives with its nutrient stock intact (Cooper et al. 1999). It intrudes into the Gyre at 100-200 m depth (Fig. 2: $6000 \mathrm{~km}$ ). This layer is also ventilated by dense, oxygenated water formed on other shelves (Melling and Moore 1995).

The interface between the Pacific and underlying Atlantic waters is a strong thermocline (warmer water at depth). Atlantic waters have followed generally cyclonic pathways around the Arctic to the Beaufort. The shallowest Atlantic water, freshened by ice-melt water in the Barents Sea (Rudels et al. 1996) and distinguished by low dissolved nutrient and oxygen, forms a lower halocline. Underlying Atlantic water arrives via the Fram Strait and Barents Sea inflows, which maintain respectively the Arctic's warm core near $400 \mathrm{~m}$ (Fig. 2: $6000 \mathrm{~km}$ ) and the cooler layer beneath (McLaughlin et al. 2002).

Canadian IPY surveys measured vertical profiles of ${ }^{230} \mathrm{Th}$ concentration in the Canada Basin in 2007 via C3O and in 2009 via GEOTRACES. Changes in the profiles since 1995 (Edmonds et al. 1998) imply change in the Arctic mid-depth circulation, based on an interpretative model outlined in Supplementary Discussion 1. Whereas the Canada Basin profiles were linear in 1995, IPY profiles deviate from linearity, with ${ }^{230} \mathrm{Th}$ atypically plentiful in Atlantic water (Fig. 3). Although ${ }^{230}$ Th-enriched water had reached $72.5^{\circ} \mathrm{N}$ in the southern Beaufort (station KC2700) in 2007 it had not spread further south. By $2009,{ }^{230}$ Th was high in Atlantic water south to the shelf edge, a signal synchronous with warmer Atlantic water penetrating the same area after 2002 (Carmack et al. 1995; Shimada et al. 2004). Together these signals are consistent with warmer Atlantic water arriving from the Alpha Ridge, which implies a change in mid-depth circulation from the normal cyclonic path - a long trajectory from Fram Strait - to an anti-cyclonic one-a shortcut. Karcher (pers. comm.) reached the same inference in modeling the observed ${ }^{127}$ I distribution, and suggested that the stronger Beaufort Gyre of this decade may have driven this change.

The $\mathrm{C} 3 \mathrm{O}$ study facilitated awareness of increased freshwater content of the Beaufort Gyre during the 2000s (Fig. 4). The centre of the gyre has migrated southeastward during the last decade, as the Gyre has become smaller and its freshwater stock more concentrated. Proshutinsky et al. (2009) attributed the increase to strengthened Ekman pumping by high air pressure over the Beaufort. McLaughlin et al. (2011), in extending the record to 2010, show that the Gyre strength and freshwater storage actually peaked during the secondyear of 
Fig. $3{ }^{230}$ Th profiles measured in 1983 near the Alpha Ridge $\left(85^{\circ}\right.$ $50^{\prime} \mathrm{N}, 108^{\circ} 50^{\prime} \mathrm{W}$ : Bacon et al. $1989)$, in 1995 at $\mathrm{AO} 1\left(72^{\circ} 32.5^{\prime}\right.$ N, $143^{\circ} 4938^{\prime} \mathrm{W}$; Edmonds et al. 1998), in 2007 at C3O's KC2000 $\left(71^{\circ} 44^{\prime} \mathrm{N}, 135^{\circ} 30^{\prime} \mathrm{W}\right)$ and $\mathrm{KC} 2700\left(72^{\circ} 28^{\prime} \mathrm{N}, 136^{\circ} 56^{\prime} \mathrm{W}\right)$ and at GEOTRACES' L2 (74'30' $\mathrm{N}, 137^{\circ} 00^{\prime} \mathrm{W}$ )

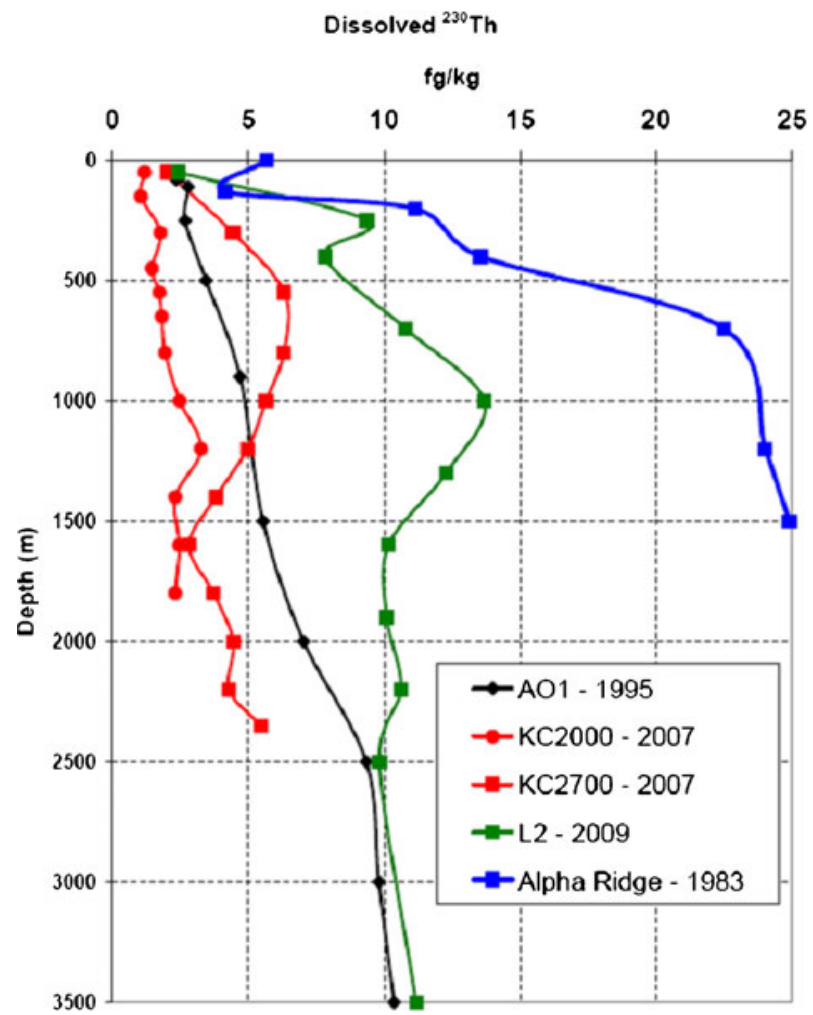

IPY (after the year of strongest anti-cyclonic forcing: Supplementary Figure 1) and has since declined.

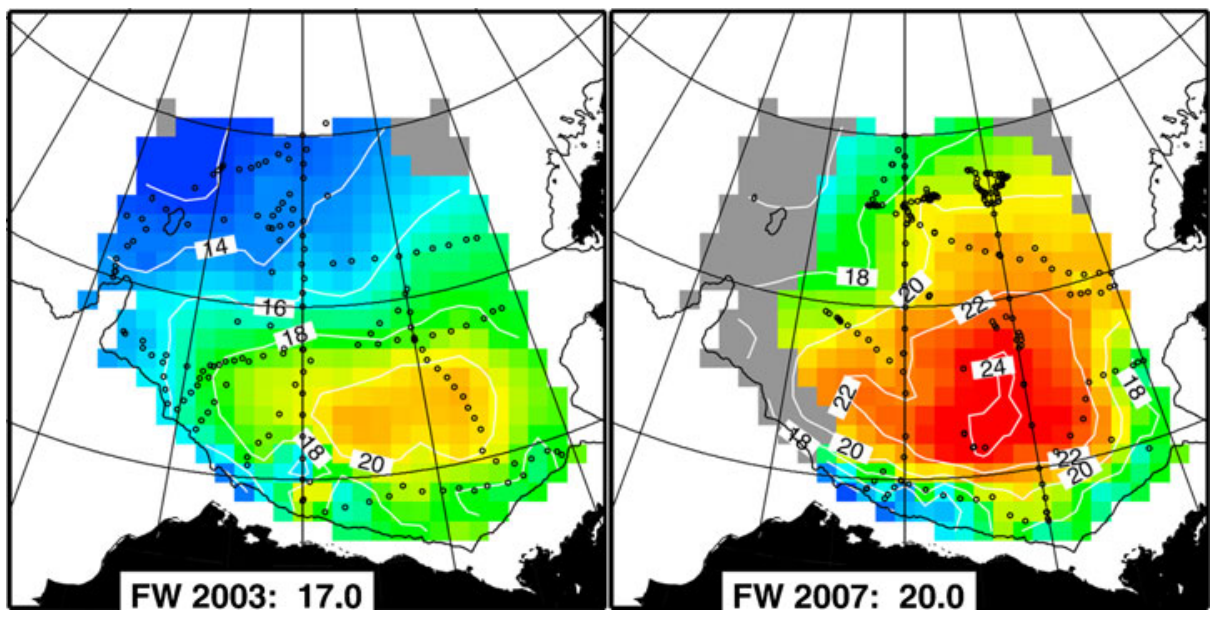

Fig. 4 Distribution of freshwater (column height in $\mathrm{m}$ ) in the Canada Basin in late summer, relative to 34.8 salinity. These frames display the build-up of freshwater during 2003-2007. The annotation is each year's freshwater inventory in 1000's km³ (Copyright 2009 American Geophysical Union. Reproduced/modified by permission of American Geophysical Union: Proshutinsky et al. 2009) 


\section{Extensive Arctic shelves are locales of through-flow and transformation}

\subsection{IPY spatial transect}

The Arctic is an unusual ocean in that shelves shallower than $500 \mathrm{~m}$ underlie more than half its area (McBean et al. 2005). The first shelf segment of C3O's transect was a $2000 \mathrm{~km}$ run through the Bering and Chukchi seas. This open-ended domain is flushed by low salinity (less than 33) water from above $100 \mathrm{~m}$ in the Pacific, which is progressively modified by biological action, cooling, river inflow and phase change. Cold water, a relict of winter freezing, can be seen at the seabed in the northern Bering and Chukchi seas (Fig. 2: 4000, $5000 \mathrm{~km}$ ). It ultimately flows down Barrow Canyon and ventilates the Arctic halocline (Weingartner et al. 2005a).

The narrow $(50-150 \mathrm{~km})$ Beaufort shelf was poorly sampled via the $\mathrm{C} 3 \mathrm{O}$ line, which moved out into deep water in this sector.

The next shallow $\mathrm{C} 3 \mathrm{O}$ segment was the Canadian polar shelf, the North West Passage from Amundsen Gulf to Lancaster Sound. It traversed a series of basins (depths of 650, 400, $400 \mathrm{~m}$ ) isolated by sills $(350,15,30,125 \mathrm{~m})$ that permit through-flow only near the surface. Canadian shelf waters are cold and strongly stabilized by freshwater (Fig. 2: 7000$9000 \mathrm{~km}$ ). Coronation Gulf, almost isolated by very shallow sills, is a peculiarity: salinity is only $28-29$ at $400-\mathrm{m}$ depth. The time to cross this shelf varies greatly, from months for surface water in boundary currents, to decades below sill depths (Carmack 2000: fig. 14). These is some mixing of Atlantic water with overlying Pacific water near central sills, where the tidal current is strong (Melling et al. 1984; Hannah et al. 2009), but Pacific water dominates the upper $100 \mathrm{~m}$, as clear in the phosphate/nitrate concentration ratio (Jones et al. 2003). Atlantic waters in eastern Lancaster Sound arrive from Baffin Bay, not from the west (Tang et al. 2004; Wang et al. 2012).

\subsection{IPY ocean observatories}

Ocean observatories were maintained by Canada' Institute of Ocean Sciences at three sites on the Beaufort shelf during IPY. Here sub-sea instruments recorded year-round: sea ice thickness, ridging, concentration, drift; ocean current, temperature, salinity; tides, waves, surge; zooplankton (via back-scattered sound).

Ice is arguably the most important indicator of Arctic marine variability. Charts from the Canadian Ice Service (http://dynaweb.cis.ec.gc.ca/IceGraph20/?lang=en) provide an overview during IPY in the Beaufort. Figure 5 displays ice concentration versus date during summer, 2006-2010, for the Mackenzie shelf and for deep $(2+\mathrm{km})$ water in the Canadian sector of the Canada Basin. Ice extent here was lowest in 2008, lagging the all-time low in Arctic-wide extent of 2007 (Comiso et al. 2008). In 2007 here, ice clearance was only a month early and freeze-up was normal, whereas in 2008, ice cleared from the Mackenzie shelf two months early and freeze-up was two weeks late.

The large-scale view of Beaufort ice from space was complemented at $\mathrm{C} 3 \mathrm{O}$ observatories by precise data from sonar: ice thickness, concentration and drift (Supplementary Figure 2). Sonar revealed that ice was thinner in autumn 2007 than in 2006, was 30-50\% thinner during the 2007-08 winter and was blown off earlier in summer 2008 than 2007. All these anomalies are consistent with enhanced westward ice drift across the Beaufort during the 2007-2008 winter.

Ice-drift measured at C3O's Site 1 (Fig. 6) reveal that ice movement during the 20072008 winter $(1900 \mathrm{~km})$ was indeed enhanced, $65 \%$ greater than during 2006-07 (1150 km). 
Fig. 5 Average sea ice concentration over the Canadian sector of the Canada Basin (top) and over the Mackenzie shelf for the summers of 2006 through 2010, as context for IPY ocean science during 2007 and 2008. The shaded background defines the 30-year median. Curves from data of the Canadian Ice Service
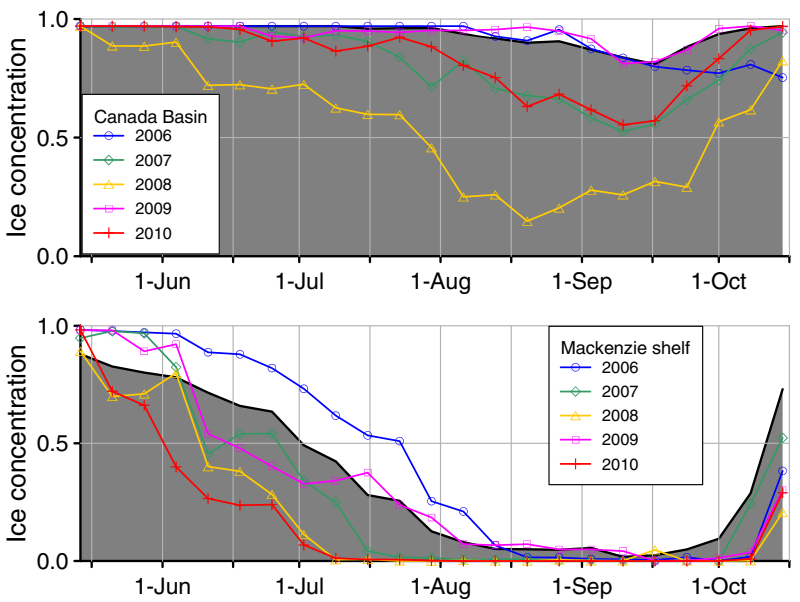

Moreover, a larger offshore component during 2007-2008 maintained a flaw lead and relatively thin young ice at the observatory all winter (Fig. 6; Supplementary Figure 2). The atypical ice cover and drift during IPY again reflect the unusually strong anti-cyclone and east wind of 2007-08.

The drift of sea ice mediates ecologically important events on Arctic shelves-flaw-lead opening and closing in winter, ice exodus in spring and summer and upwelling. Abrupt springtime declines in thickness (Supplementary Figure 2) indicate that the ice was blown north-west before melting in both years, quickly opening marine habitat to air-breathing mammals. With ice sent northwestward by wind, little melt-water was left on the shelf in either IPY summer and river inflow will have followed behind under the same influence, leaving shelf waters more saline and less stratified during these summers.

The ice-drift vector (Fig. 6) is proxy for surface stress on the ocean, strongly westward during both IPY winters. Because Earth's rotation causes the top 10-20 m to move to the right of surface stress - offshore during IPY - there was a compensating shoreward movement at greater depth. Shoreward flow over a sloping seabed lifts more saline nutrient-rich Pacific water towards the photic zone, promoting primary production. Bottom current (not shown) at Site 1 did indeed move water shoreward during IPY, continuously supplying nutrient-rich water to the inner shelf; the shoreward span of the progressive vector for each year was about $1200 \mathrm{~km}$. The average onshore flow was $3.0,4.2,3.5$ and $3.0 \mathrm{~km} / \mathrm{d}$ during consecutive ice/no-ice intervals of 2006-08, revealing strongest upwelling when ice drift was fastest, during the 2007 summer and subsequent winter.

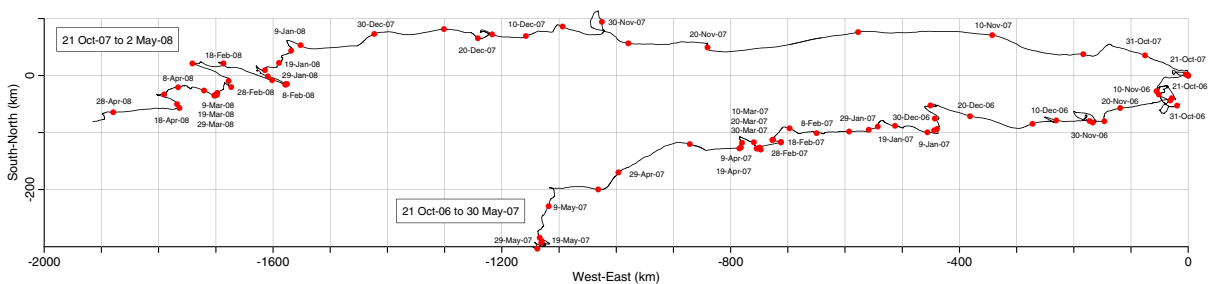

Fig. 6 Pseudo-trajectories of sea ice drift at C3O's Mackenzie shelf observatory during the two winters of IPY. Crosses delineate each 1-day interval with red circles every 5 days 
Upwelling in the southern Beaufort moves low salinity water from the shelf to the Gyre and replaces it with more saline water from deeper in the Gyre. The exchange increases the vertical density contrast in the basin and reduces it on the shelf. Its outcomes are less ice, more light, reduced stratification and improved nutient supply on the shelf and the opposite in the basin. The year 2007 was exemplary in this respect.

See Supplementary Discussion 2.

\section{The Arctic Ocean exports water and ice to the Atlantic}

In eastern Canada, C3O surveyed the Arctic-Atlantic outflow via a 3400-km section from Lancaster Sound to the Labrador Sea. The section missed the northward current of Atlantic water near Greenland (Zweng and Münchow 2006), but did sample its re-circulating branch (Fig. 2: $9000 \mathrm{~km}$ ), beneath the cold Canadian Arctic through-flow (CAT) in western Baffin Bay (Melling et al. 2001; Lobb et al. 2003; Münchow et al. 2006; Melling et al. 2008).

South of Davis Strait, the C3O section passed into the warmer, weakly stratified cyclonic gyre of the Labrador Sea (Fig. 2: $11500 \mathrm{~km}$ ), locale of occasional deep wintertime convection that injects Labrador Sea deep water into the global overturning circulation (Yashayaev et al. 2008). The section crossed back into the Arctic outflow on the Labrador slope, where it carries nutrients to the domain of Canadian Atlantic fisheries (Drinkwater and Harding 2001).

The flux of volume via CAT is the cross-strait integration of current assuming that interpolated values are valid between sites of observation. Surveys in the 1960s, when such observations were sparse, determined that the flow across the Canadian polar shelf was 22000-54000 km $\mathrm{y}^{-1}$ (Melling 2000), roughly half the total Arctic outflow. It reaches Baffin Bay via Nares Strait, Cardigan Strait (plus Hell Gate) or Lancaster Sound (Melling et al. 2008). See Supplementary Discussion 3 for additional information.

A CAT cross-section was first measured in detail in Nares Strait, by ship-based Doppler sonar and CTD in 2003. The survey revealed that flow was concentrated in a fast narrow $(5-10 \mathrm{~km})$ streams within the wider channel (Münchow et al. 2007). Data from 15 moorings here during 2003-2006 revealed additional complication-temporal variation in structure: the 'river' at the surface mid-channel under moving ice migrated to 100-m depth on the western side when ice became fast (Rabe et al. 2010). These surveys reinforced the understanding that accurate flux measurement either requires data at spacing tight enough $(5 \mathrm{~km})$ to permit accurate interpolation, or the assumption that a once-measured crosssectional pattern of current persists, so that data from a few sites are subsequently adequate. The former approach to IPY observations was taken in Nares and Cardigan Straits and the latter in Lancaster Sound.

The pre-IPY estimate of CAT (see Supplementary discussion 3) was the sum of estimates for different periods of observation by different methods for each gateway, with few data from above $40 \mathrm{~m}$ anywhere. IPY-Canada provided the first-ever opportunity to measure at all gateways concurrently. A $38-\mathrm{km}$ section across Nares Strait was instrumented with five Doppler sonar measuring current and ice drift, while salinity, temperature and ice thickness were measured on interleaved taut-line moorings. An 8-km section across Cardigan Strait was monitored from three moorings, while two locations on a $60-\mathrm{km}$ crossing of Lancaster Sound were instrumented with Doppler sonar and ICYCLER.

The Arctic outflow through Lancaster Sound was unusually weak during the IPY, only $0.25 \mathrm{~Sv}$ or half the long-term average (Fig. 7). The weaker flow may be linked to the anomaly in Arctic sea-level pressure (Supplementary Figure 1), since Prinsenberg et al. (2009) have 


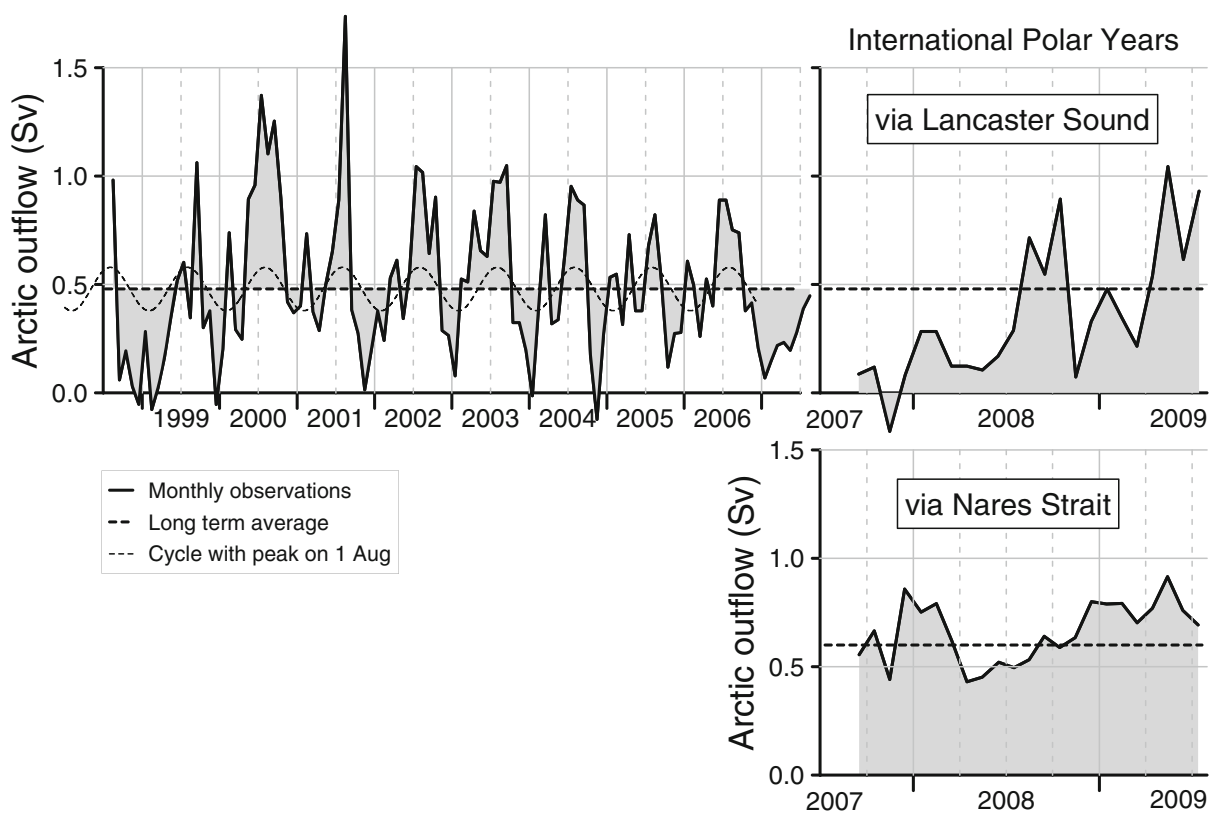

Fig. 7 Monthly means of Arctic outflow flux through Lancaster Sound (top, incorporating a recent downward revision of the long-term mean from 0.7: SJ Prinsenberg, pers. comm. 2011) and Nares Strait (bottom; flux in the top $35 \mathrm{~m}$ not included). A few months of weaker flow through Nares Strait began with fast-ice formation in early April 2008. The sinusoid depicts an annual cycle

calculated that $42 \%$ of the monthly flux here is correlated with wind anomalies in the Beaufort Sea; the strong Beaufort anticyclone during the IPY will have drawn down sea level along the edge of the Canadian polar shelf.

The 0.67-Sv outflow (excluding the top $35 \mathrm{~m}$ ) via Nares Strait during IPY was $20 \%$ higher than the 2003-2006 average, with unusual local ice conditions the likely cause of the enhancement. Orographically amplified wind is a strong influence on current here when ice is mobile (Samelson et al. 2006; Samelson and Barbour 2008), but fast ice between midwinter and midsummer normally isolates the ocean from wind stress and weakens current via friction. However fast ice was present for only two months during the winter of 2007-2008 (early April to early June: Fig. 7) and did not form at all the following year. The consequent impact on Nares Strait fluxes is clear in Fig. 7.

The narrowness of Arctic outflows crossing the Canadian polar shelf reflects the dominance of internal pressure gradients (baroclinicity) in their dynamics (Leblond 1980). There are arguments to suggest that the above-noted seasonal change in the cross-sectional geometry of the flow may reflect the changing influence of the ice cover (Supplementary Discussion 4).

Several numerical simulation models were developed at the University of Alberta and at the Bedford Institute of Oceanography during the IPY to investigate CAT dynamics. Technical details of two, PAN and the higher resolution CAA, are included as Supplementary Discussion 5; an example of CAA's output appears as Supplementary Figure 4, with commentary in Supplementary Discussion 6. The model CAA calculates a 1999-2004 average flux of $0.6 \mathrm{~Sv}$ via Lancaster Sound, including $49 \mathrm{mSv}$ as fresh water, and similar values via Nares 
Strait. Figure 8 compares the models' simulations with observations (Wang et al. 2012). CAA's results are close to observations in Lancaster Sound on average ( $0.60 \mathrm{~Sv}$ vs. $0.53 \mathrm{~Sv}$ observed), but simulated seasonal variation is much smaller. Fluxes calculated by the PAN model are $2-3$ times larger (1.79 Sv via Lancaster; $2.56 \mathrm{~Sv}$ in total) and their seasonal variation is unrealistically large.

\section{Atmospheric events drive ocean processes on many time scales}

IPY marine research clearly demonstrates that atmosphere, ocean, ice, land and life systems interact strongly in Arctic. The impacts of atmospheric variation on the freezing and thawing of ice, on the dispersal of river inflows, on ice drift, currents and upwelling are particularly obvious in results discussed here. The ocean's response to storms is in the same class, and of great practical importance.

Arctic storms generate waves and sea-level surges and drive ice drift, currents and ocean mixing. Their human impact via shoreline erosion, sediment transport and coastal flooding can be devastating, especially along the low-lying Beaufort coast. Long upwind fetches without ice cover, most common in autumn, are linked to the most damaging sea conditions. IPY-Canada's project on Arctic storms focused on storms crossing the open water of the Chukchi and southern Beaufort and making landfall at the Mackenzie delta.

A distinctive aspect of the coastal Beaufort is the spreading Mackenzie River plume. Difference in density between the plume and the ocean weakens their dynamical coupling, so that the former responds rapidly to wind. Mulligan et al. (2010) mapped the Mackenzie plume near the Delta during a 12-day period in August 2007, measuring current, temperature and salinity from waters of less than 2-m depth to several hundred kilometres offshore. Within $20 \mathrm{~km}$ of shore, the water column was homogenous from top to bottom because wind and waves had completely mixed the river and ocean layers. A separation into two layers near the 2-m isobath was associated with strong lateral gradients (fronts) fronts in temperature, salinity and current. The movements of these fronts, by as much as $40 \mathrm{~km}$ per day, were dominated by wind.

Calculations by IPY hydrodynamic models have demonstrated that two layers can coexist beyond the 2-m isobath because the stratifying effect of river flow overwhelms the mixing potential of the wind. The resulting density difference between the layers partially decouples them, so that the floating plume can be driven hundreds of kilometres offshore by

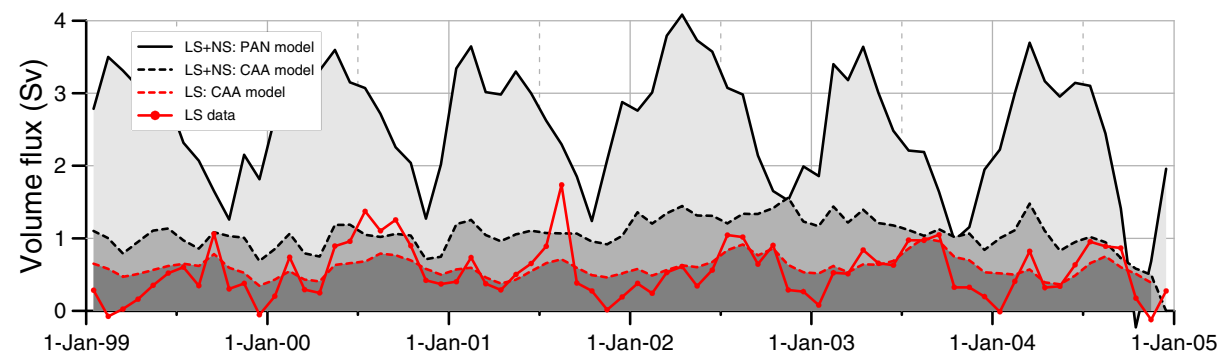

Fig. 8 Comparison of measured and modeled volume flux across the Canadian polar shelf, 1999-2004. Lancaster Sound observations (solid red \& symbols) and CAA-model simulations (dashed red); Lancaster Sound plus Nares Strait CAA-model (dashed black) and PAN-model (solid black). 
east wind, with associated drawdown of coastal sea level (Mulligan et al. 2010). The opposite also occurs: coastal sea level rises and flooding occurs when wind drives the upper layer rapidly towards the coast. IPY research has revealed that the two-layer ocean structure is an important factor in accurate surge and flood forecasting in the Beaufort; models must incorporate ocean density structure via a third dimension in order to determine when and where weakly coupled layers form and their thickness. These characteristics determine the mass of water to be moved by wind and the strength of frictional resistance.

Research has also revealed that backed-up river flow contributes to coastal flooding during surges, so that reliable flood forecasts also require an integrated hydrological model for the Delta.

Waves are important consequences of storms. The low elevation and thermokarst vulnerability of the ice-bonded shoreline are notable features of the Mackenzie Delta in this context, allowing rapid coastal erosion during storms. Destructive waves are generated by prolonged strong winds blowing over long fetches. With the northward retreat of the Beaufort ice edge during recent decades, there is now a broad ice-free expanse extending from the Delta to the Chukchi Sea by late summer. This permits more energetic waves from this quarter than formerly, with potential for accelerated coastal erosion during north-west gales. On the positive side, the extensive shallows $(0-20 \mathrm{~m})$ that surround the Delta are a buffer wherein some wave energy is dissipated via bottom friction, wave steepening and breaking. It is important to understand this buffering so that effective plans for mitigation of climate-change impacts may be developed.

IPY-Canada's Arctic Storms Project mounted a study in the summer of 2008 to calibrate the dissipation of wave energy in its shallow-water wave model for the Beaufort. Waves were measured at a $5 \mathrm{~m}$ deep site to validate the model's parameterization of bottom friction and at 35 and $55 \mathrm{~m}$ depths ( $\mathrm{C} 3 \mathrm{O}$ sites $1 \& 11)$ to characterize the waves incident from offshore. Wind was measured offshore at Pelly Island $\left(69.6^{\circ} \mathrm{N} 135.3^{\circ} \mathrm{W}\right)$. The results of this IPY study have guided the representation of wave friction in shallow water of the Beaufort, and have subsequently permitted the successful simulation of coastal waves shown in Fig. 9 (Xu et al. 2011).

This IPY study has paved a way towards an operational wave forecast in the Beaufort, where extensive shallows, soft mud, a large river and sea ice are new challenges to modeling.
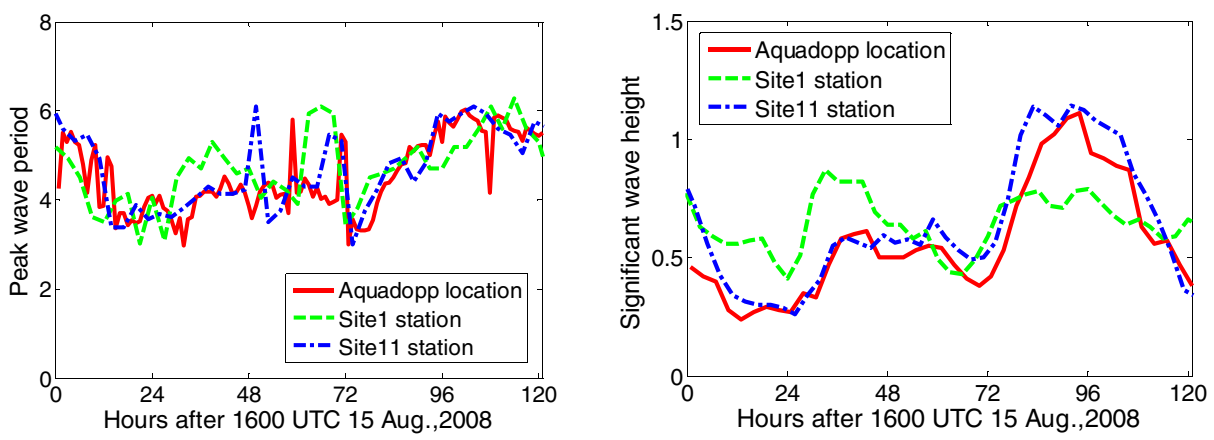

Fig. 9 Peak period (left) and significant wave height (right) at IPY ocean observatories during 5 days in August 2008. IPY models successful in replicating the observed evolution of the wave field during this storm. Sites Aquadopp, 1 and 2 are at depths of 5, 35 and $55 \mathrm{~m}$ near the Mackenzie delta 


\section{Marine sediments store the imprint of the Arctic's past}

Variations in insolation linked to cycles in Earth's orbit have triggered ice ages at intervals of $10^{5}-10^{6}$ years during the last 2 million years, cycles that have been well studied in aquatic sediments. Changes at shorter intervals of 10-1000 years are poorly known. Models predicting future climate can be tested against only a few decades' direct observations in the Arctic, but there is a much longer record of past climate in proxy's preserved in sediments. The objective of the IPY-Canada project, 'Natural Climate Variability and Forcing in the Arctic', was new data on Canadian Arctic climate during the Holocene.

Marine sediments were collected by piston coring at key locations (Fig. 1). Seabed surveys by multi-beam mapping and sub-bottom profiling $(3.5 \mathrm{kHz})$ sonar guided the selection of sites. Attributes of preserved dinoflagellate cysts provided proxies for seasurface temperature (SST), salinity and annual ice-cover duration based on the modern analogue technique (Ledu et al. 2010). Cores of lacustrine sediment (silt and/or clay with interleaved bands of moss) were collected on Victoria and Melville Islands using a Livingston corer. In these cores, preserved pollen, spores and head capsules of chironomids provided proxies for air temperature via the weighted average partial least squares and modern analogue techniques (Fortin and Gajewski 2010).

Chronology was based on ${ }^{210} \mathrm{~Pb}$ data, on AMS- ${ }^{14} \mathrm{C}$ ages (for mollusk shells in marine sediments, for plant chironomids fragments and sediment samples in lake sediments) and on well-dated reference curves for geomagnetic variations recorded in clays (Barletta et al. 2010). Via evidence of uninterrupted deposition, we know that deep basins have had rapid accumulation during the Holocene $(1-1.8 \mathrm{~mm} / \mathrm{y})$. The accumulation rate of lacustrine sediment was $10 \mathrm{x}$ slower.

Cores from Jones Sound and Barrow Strait comprise the marine record from eastern Arctic Canada (Fig. 10). They reveal the early Holocene (11000-6000 cal BP) in Barrow Strait to have been relatively cold, with summertime SST as much as $2{ }^{\circ} \mathrm{C}$ cooler than today. Such harsh conditions reflect the presence of cold melt water from retreating Innuitian and

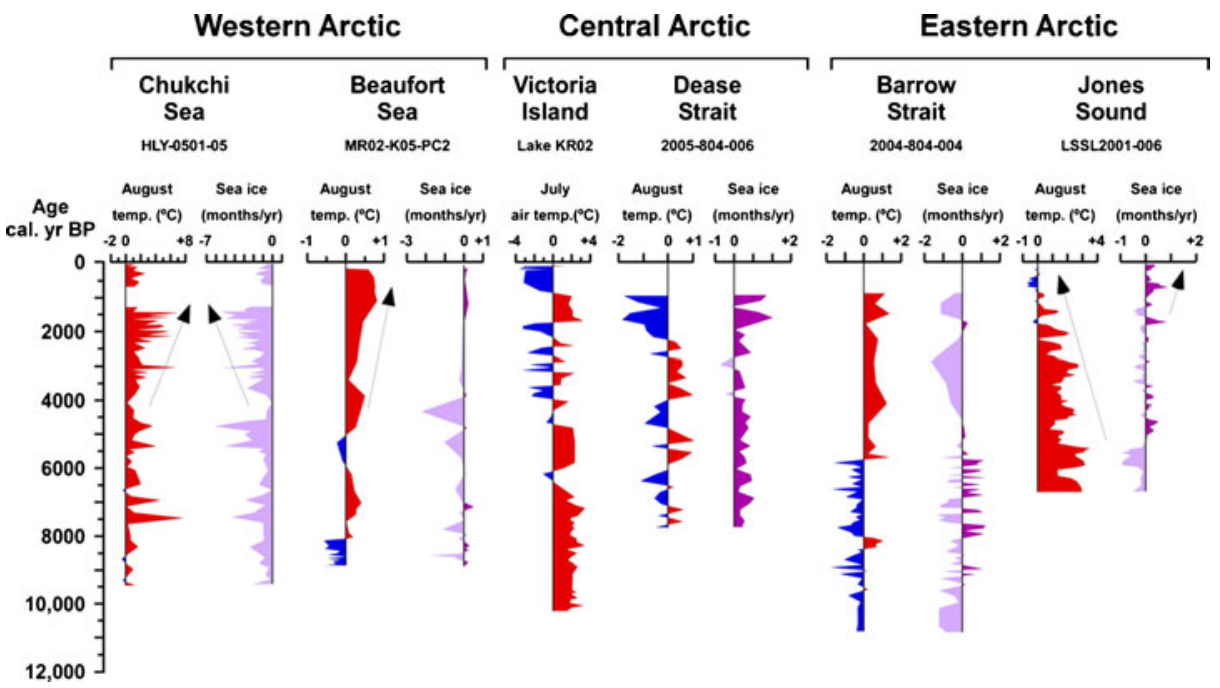

Fig. 10 Paleo-reconstructions of summertime sea-surface temperature and sea ice duration from 5 marine cores and air temperature reconstructions from a lacustrine core. Values are departures from the mean of each parameter at the core site. Black arrows identify trends 
Laurentide ice sheets (England et al. 2006; Carlson et al. 2008). In contrast, the yearly duration of sea ice varied within \pm 1 month of today. Climate subsequently warmed with increasing solar insolation (9000 BP: Berger 1978), creating the Holocene 'thermal maximum', whose timing and extent varied regionally. Summertime SST peaked around $6000 \mathrm{cal}$ $\mathrm{BP}$ in Jones Sound, $2-3.5^{\circ} \mathrm{C}$ warmer than today. The maximum in Barrow Strait, about $1{ }^{\circ} \mathrm{C}$ above today, occurred at 4500 cal BP. During subsequent cooling in Jones Sound, SST decreased via a series of 1800-y oscillations.

Information on the south-central polar shelf has been derived from a marine sequence in Dease Strait (Ledu et al. 2010) and a lacustrine core on Victoria Island (Fortin and Gajewski 2010). Sea surface conditions in Dease Strait underwent a series of 750-1200 y oscillations during this time, with temperatures from $-2^{\circ}$ to $+1^{\circ} \mathrm{C}$ relative to today. The most recent cold spell, 2200-1000 cal BP, was also the coldest at $2{ }^{\circ} \mathrm{C}$ below modern. Sea ice was present for $1-1.5$ months longer than today during most of the interval, except briefly at 3800 and $3000 \mathrm{cal}$ BP. The lacustrine core on Victoria Island revealed synchronous and comparable variation in temperature, between $3.4^{\circ} \mathrm{C}$ warmer and $3.5^{\circ} \mathrm{C}$ colder than today.

The Beaufort Sea experienced fluctuations between $0.5^{\circ} \mathrm{C}$ colder and $0.4{ }^{\circ} \mathrm{C}$ warmer than today in the early Holocene (9000-5000 cal BP). However, this interval was much warmer in the Chukchi Sea; summer SST reached $1-7{ }^{\circ} \mathrm{C}$ above modern values and the annual duration of sea ice was 1-6 months shorter. Both areas were warm around $5000 \mathrm{cal} \mathrm{BP}$, cool at $4000 \mathrm{cal} \mathrm{BP}$ and warm again subsequently. The highest anomaly in the Beaufort was about $+1{ }^{\circ} \mathrm{C}$, within the modern range, and associated with ice cover little different from today. That in the Chukchi again reached $+7{ }^{\circ} \mathrm{C}$ at about $1500 \mathrm{cal} \mathrm{BP}$ and was linked to a much reduced annual ice presence (McKay et al. 2008).

Opposing swings of temperature in the eastern and western areas of the Canadian Arctic are obvious. In Jones Sound, a cooling trend started about 6000 BP, consistent with other sedimentary records (Kaufman et al. 2009), but conditions on the Pacific side were warmer than today throughout the Holocene, with much less sea ice in the Chukchi in the late Holocene. All cores revealed persistent temperature oscillations of 1000-3000 y period.

The spatial pattern in temperature and sea ice inferred from cores suggests a link to a strongly positive Arctic Oscillation (e.g., Polyakov and Johnson 2006; Darby and Bischof 2004) during the early Holocene and later to a persistent negative phase. The same inference was made in earlier studies (Dyck et al. 2010; Rimbu et al. 2003).

A second IPY study of marine sediments investigated a geochemical signature of Arctic paleo-climate (Macdonald and Gobeil 2011). Box-core samples of the uppermost half metre of sediment taken at twenty-nine shelf, slope and basin locations were analyzed to determine the concentrations of aluminum, manganese, additional inorganic components and organic carbon. The data have revealed the changing budgets of aluminum and manganese in the Arctic Ocean and a link to sea level.

Most Arctic manganese comes from rivers or coastal erosion; little is exported. Manganese profiles in sediments reflect the recycling of material, initially deposited on the continental shelf and its ultimate burial in the slopes and basins. The colour-banding of long sediment cores reveals varying manganese enrichment synchronized with cycles of glaciation. A budget for manganese in the Arctic implies that the bands are a consequence of sea-level change linked to the accumulation and wasting of ice caps (Macdonald and Gobeil 2011). The continental-shelf fraction of the Arctic Ocean, presently more than $50 \%$, decreases quickly as sea level falls because the shelves are shallow. Sea level was $120 \mathrm{~m}$ lower during the last glacial maximum and river flow and coastal erosion were greatly reduced; the manganese flux was retained in the sub-aerial permafrost of outwash plains and little reached the Arctic Ocean. As ice sheets shrank, this manganese was remobilized via 
increased river flow, rising sea level and resumed coastal erosion. A simultaneous resumption of marine algal production provided organic carbon to chemically reduce the manganese stored in the progressively transgressed Arctic alluvial plains.

This novel IPY work has provided proof that climate interacts with the abundance and cycling of chemical elements in subtle and informative ways.

\section{Arctic seas are habitat for marine life}

Northern people have strong reliance on Arctic biogeography and food webs. Unfortunately, historical data on Arctic marine ecology are much scarcer than data describing the marine environment. However, by extending many existing Arctic environmental records, the IPYCanada program provided contextual information important to ecological variability that can only be glimpsed in biological records. For example:

Is new habitat appearing in Canadian Arctic waters? Sea ice is arguably the most influential component of the Arctic marine environment. The recent decrease in multi-year ice is well known-Arctic-wide extent has been shrinking at $12 \%$ per decade. Its decrease in Canadian waters, however, has been much smaller (1-2\% per decade) and statistically insignificant (at $95 \%$ level) except in a few small areas (Tivy et al. 2011). Decreases in the combined extent of multi-year and first-year ice have been larger (2-4\% per decade on the northern polar shelf, $10 \%$ per decade in Baffin and Hudson bays), but significant only in western Parry Channel (2\% per decade) and in Baffin and Hudson Bays. The decrease in multi-year ice in the Beaufort is statistically significant only in the Alaskan sector. The weakness of trends in the Canadian Arctic implies that marine life will co-exist here with summertime sea ice for some years to come.

The extent of northern sea ice has decreased also in winter, but at latitudes outside the Arctic (e.g., Labrador Sea). Within the Arctic Ocean, the extent of first-year ice in winter has actually expanded by $36 \%$ as the perennial pack has shrunk. It remains to be seen whether this new expanse becomes habitat for organisms that prefer first-year ice over multi-year. Meanwhile, the average thickness of first-year ice has not changed noticeably over two decades in the Beaufort Sea (Fig. 11; also Melling et al. 2005).

Are ecologically important barriers disappearing? The most obvious ecological barrier in the Canadian Arctic is the multi-year ice massif on the Canadian polar shelf. This has inhibited the movement of marine mammals between the Atlantic and Pacific sides of Canada for at least a few thousand years (Dyke et al. 1996). It divides distinct populations of walrus, beluga and bowhead. During both summers of the IPY, the ice massif shrank until

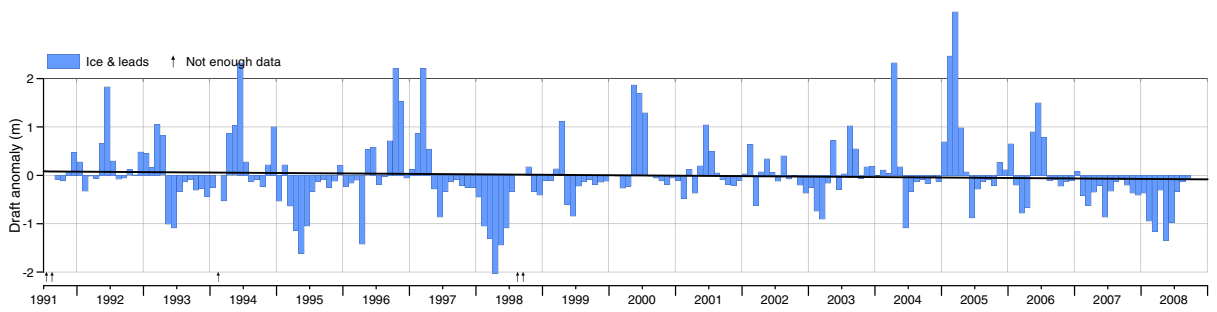

Fig. 11 Monthly anomalies in the draft of drifting sea ice at C3O's Site 1 observatory on the Mackenzie shelf. The solid line shows the small trend, which is indistinguishable from zero at the $95 \%$ level 
there was (briefly) an open route between Baffin Bay and the Beaufort. However, large summertime losses of sea ice have occurred here at decadal intervals since observations began-1962, 1969-1971, 1980-1981, 1998-1999 (Melling 2002). In each instance, multiyear ice reestablished dominance within 4-6 years (Dumas et al. 2007). Nonetheless, if the Arctic perennial pack continues to shrink, there will sometime no longer be enough old ice to repopulate the Canadian polar shelf after summers of extreme melting. At such time, the ice barrier will disappear.

\section{Is the acidity of Arctic waters rising in response to increased atmospheric carbon dioxide?}

Approximately one third of the anthropogenic carbon dioxide to date has been absorbed by the ocean. The uptake has increased the acidity of seawater and reduced its carbonate-ion concentration. Decreased carbonate places some plankton and shellfish at risk because carbonate ions are required to build shells.

The impact of increased atmospheric carbon dioxide is greater on high-latitude oceans because cold water dissolves more gas. C3O's observations in the Canada Basin (Yamamoto-Kawai et al. 2009) and CATs' on the Canadian polar shelf (AzetsuScott et al. 2010) revealed waters at 100-200 m depth already under-saturated with respect to aragonite, one form of calcium carbonate found in plankton. The water at this depth forms on Arctic shelves in winter; it is cold and rich in carbon dioxide acquired through remineralization of organic material and by absorption of anthropogenic emissions from the atmosphere. Because of its damaging potential for calcifying biota, under-saturation could alter the species composition of Arctic ecosystems relatively soon.

Are the constraints on Arctic marine productivity changing? Two constraints on Arctic primary production were known before the IPY: light and dissolved nitrate (Hill et al. 2005). Nitrate is usually low in Canadian Arctic surface water (Tremblay et al. 2006), which loses nitrate during transit across the Bering-Chukchi shelf (Yamamoto-Kawai et al. 2006).

Because scarcity of iron is known to limit primary production globally, GEOTRACES conducted a study of iron's role in Arctic marine production during IPY. Incubation experiments at several light, iron and nitrate levels were completed using water from 29-m depth in the southern Canada Basin in September 2009; here picoplankton were the dominant producers, nitrate was below $0.13 \mu \mathrm{M}$ and iron was $0.154 \mathrm{nM}$. Trials spanned three light levels (50,10 and $1 \%$ of surface), two concentrations of iron (in situ, in situ plus $1 \mathrm{nM}$ ) and two of nitrate (in situ, in situ plus $10 \mu \mathrm{M}$ ).

All treatments with added nitrate boosted phytoplankton, confirming limitation by nitrate. Enhanced lighting further boosted production, revealing a concurrent light limitation. Added iron boosted primary production only at light levels below $10 \%$, showing that the photosynthetic need for iron was greater at low irradiance or equivalently at greater depth or later in autumn.

In common with light and nitrate, iron has a seasonal abundance regulated by sea ice. It accumulates in ice over the winter via aeolian deposition (Measures 1999) or via entrainment of suspended sediment in shallow-water (Tovar-Sanchez et al. 2010). It is transferred from melting sea ice to surface waters during summer and supplemented by rivers at the Arctic margin (Measures 1999). The IPY study suggests that iron deficiency presently ends the growing season as daylight diminishes. Over the Arctic basins, where less ice melts and rivers are remote, iron scarcity may be an even stronger control. 


\section{Variability and change in the marine Arctic-Can we tell the difference?}

A useful understanding of Arctic change and its impacts is urgently sought, but elusive because existing records are short. Few span three decades and fewer a half century. Because natural variability in key environmental attributes - ice cover, circulation, nutrients, temperature and salinity - is large, reliable discrimination of trend and variability is presently challenging.

IPY provided two realizations of an oceanographic transect, summer only, from Victoria to Halifax. These show similarities in ocean structure and properties and also dramatic differences. Although IPY, with only a two-year perspective, provides no skill in detecting trends, it is undeniable that future repetition of these transects will support a steady increase in this skill. Indeed, C3O's successful demonstration that Coast Guard's Arctic patrols could maintain a reliable and cost-effective watch on Canada's oceans is an important IPY outcome.

However, a standalone interpretation of C3O's observations from ships in transit is ambiguous: transects provide a sequence of brief, unsynchronized glances at oceans undergoing rapid seasonal change. $\mathrm{C} 3 \mathrm{O}$ also included marine observatories to offset this shortcoming - instruments on moorings at key locations that recorded data year-round.

An updated perspective on oceanic change, where earlier observations exist, has been a valuable output of IPY. Such includes warmer Pacific and Atlantic layers in the Canada Basin during IPY, a further diminished cover of perennial ice, concomitant increased light for summertime primary production but more vigourous Ekman pumping of the Gyre that has concentrated freshwater and increased the difficulty of mixing nutrients (heat, salt) into the photic zone (see Supplementary Discussion 7).

C3O's marine observatories during IPY extended our temporal perspective beyond antecedents. That on the Mackenzie shelf (Section 5) is distinct from many in the Arctic in representing a shelf (not a basin) and first-year (not multi-year) ice. Melling et al. (2005) discussed twelve years' observations here, seeing no trends in the thickness and character of sea ice during 1991-2003. The update of this analysis through IPY (to 17 years) does not change the conclusion (Fig. 11). First-year ice appears relatively insensitive to factors causing loss of Arctic multi-year ice.

Even during summer, ice in the Canadian Beaufort has changed less than elsewhere. Figure 12 displays 30-year anomalies in the total accumulated concentration (TAC: average ice concentration within a defined area and interval, here mid May to mid October) of sea ice for two regions of the Canadian Beaufort; TAC has advantage over single-date statistics in that it integrates ice concentration over representative interval of time. The 30-year trends are downward in both basin and shelf areas, but neither is statistically significant at the $95 \%$ level. In fact, TAC in the Canadian part of the basin has been high, except in 1993, 1998 and 2008.

The low confidence in calculated trends is humbling because these ice time series are some of the longest environmental records in the marine Arctic. It is reasonable to generalize that year-to-year variation has a high but unknown impact on trends calculated from the much shorter series that comprise most of our knowledge of the marine Arctic.

\section{Conclusions}

Canada's IPY research has strengthened our knowledge of the Arctic Ocean as an element of interacting physical and geochemical systems that span the atmosphere and adjacent oceans. 
Fig. 12 Annual anomalies in the Total Accumulated Concentration of sea ice over the basin (72$76^{\circ} \mathrm{N}$ deeper than $1000 \mathrm{~m}$ : top ) and shelf (bottom) of the Canadian Beaufort Sea TAC is the average ice concentration for 15 May-15 October. Shading denotes $95 \%$ range of confidence for the trend lines. http://dynaweb.cis.ec.gc.ca/ IceGraph20/?lang=en)
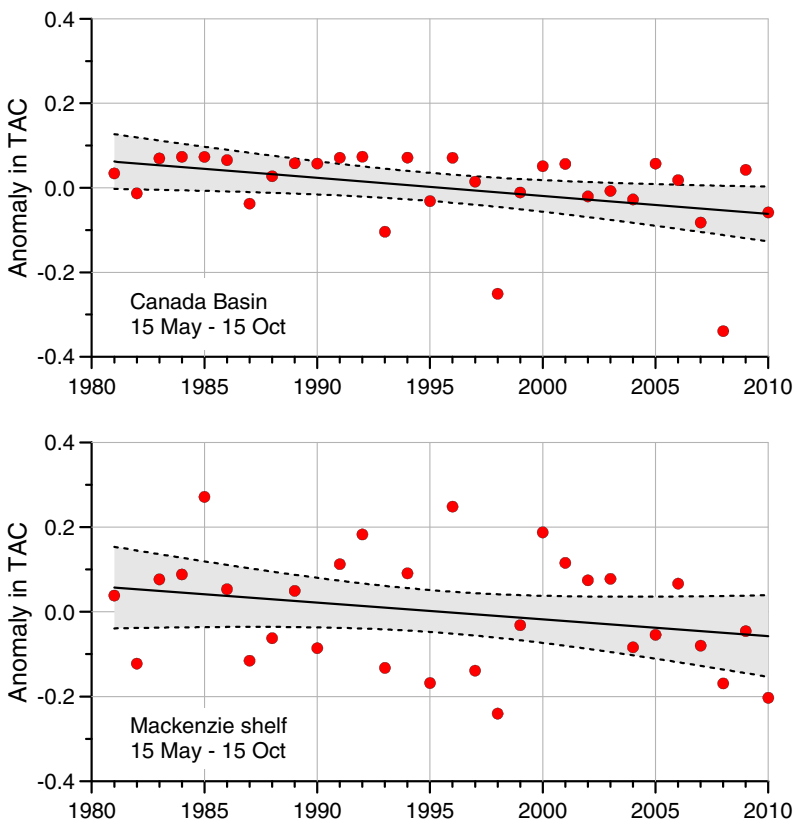

The nature of the Arctic is determined by the influence and strength of these interactions, which fluctuate over days to decades.

IPY sediment cores reveal cycles in Canadian Arctic climate since the Ice Age. These have been asymmetric - warm intervals with less ice in the west have coincided with cool intervals and more ice in the east and vice versa. The pattern mimics the asymmetry of the atmospheric Arctic Oscillation, whose winds may have caused it.

IPY studies demonstrate that recent changes in Canadian Arctic waters have also been strongly linked to variations in the pattern and strength of winds.

IPY research has developed expertise to predict hazardous winds, waves and surges generated by Arctic storms when ice is far from shore, and conversely to predict the enhanced potential for storm development over wide ice-free expanses of warm water. The extent of the latter has increased in recent summers.

Sea ice is the key variable of Arctic seas; its variations strongly affect the ocean's environment and ecosystem. IPY research has shown that sea ice has changed less in Arctic Canada than elsewhere. In the Canadian Beaufort, downward 30-year trends in summertime ice extent are not distinguishable with confidence from normal variability. Observations of first-year ice thickness here reveal no change over two decades.

A perennial ice massif has divided distinct populations of marine mammals in the eastern and western Canadian Arctic for millennia. IPY study reveals this barrier still intact at present, but continued shrinkage of the Arctic multi-year ice pack could ultimately eliminate the reservoir from which the massif is replenished.

Variable Arctic outflow across the Canadian polar shelf is a link in the global hydrologic cycle and key to change in the Arctic Ocean. The IPY has provided the first comprehensive observations of Canadian Arctic through-flow, identifying varying sea level, wind and ice state as important forcing factors. The impact of climate change affects on through-flow remains uncertain because the dynamics of flow forcing and control are poorly understood. 
Freshwater volume in the Canada Basin increased during the last decade, reducing the nutrient supply for plankton in the sun-penetrated upper ocean. Additional sea-ice meltwater in Canada's Arctic has also aggravated the acidification of seawater by absorption of anthropogenic carbon dioxide. IPY research has also revealed the limitation of primary production in the Canada Basin by available dissolved iron. This occurs where light levels are low, as in deep $(50 \mathrm{~m})$ plankton layers or in autumnal polar twilight.

High variability seriously hinders the discrimination of real change from natural variation in the typically short (less than $30 \mathrm{y}$ ) available data sequences. Sustained environmental observations are clearly essential for monitoring and understanding change in the marine Arctic.

Canada's marine IPY projects have built computer-based tools for Arctic Ocean simulation and prediction. Some are candidates for migration into Canadian operational marine forecasting services. Others are science-based tools for good governance in marine resource management and impacts assessment.

All of IPY-Canada's marine projects have been international in coordination, participation, scope and impact. They have fostered productive relationships with international partners.

Acknowledgments Research presented here was supported by the Government of Canada program for the International Polar Year, Fisheries and Oceans Canada, the Natural Sciences and Engineering Research Council and by many collaborating institutions in Canada and abroad. Field expeditions were competently supported by officers and crews of Canadian Coast Guard and staff of the Polar Continental Shelf Project. The work would not have been possible without the interest and approval of northerners in small communities across the Arctic. We thank the following collaborators for their assistance and contributions: EC Carmack, K Gajewski, J. Hamilton, C Hillaire-Marcel, X Hu, MT Maldonado, R Mulligan, A Münchow, C Payne, SJ Prinsenberg, B Rabe, DM Semeniuk, DB Scott, G St-Onge, A de Vernal, Q Wang, F Xu. We also acknowledge the contributions of innumerable managers, students and support personnel who assisted with project management, scientific equipment preparation, field studies, data processing and many other tasks.

\section{References}

Azetsu-Scott K, Clarke A, Falkner KK, Hamilton J, Jones EP, Lee C, Petrie B, Prinsenberg SJ, Starr M, Yeats P (2010) Calcium carbonate saturation states in the waters of the Canadian Arctic Archipelago and the Labrador Sea. J Geophys Res 115:C11021. doi:101029/2009JC005917

Bacon MP, Huh CA, Moore RM (1989) Vertical profiles of some natural radionuclides over the Alpha Ridge, Arctic Ocean. Earth Planet Sci Lett 95:15-22. doi:10.1016/0012-821X(89)90164-7

Barletta F, St-Onge G, Channell JET, Rochon A (2010) Paleomagnetic dating of Holocene Western Canadian Arctic sediments: combined use of the paleomagnetic secular variation and global spherical harmonic model of the geomagnetic field. Quatern Sci Rev 29:2315-2324

Berger AL (1978) Long-term variations of daily insolation and quaternary climatic changes. J Atmos Sci 35:2362-2367

Beszczynska-Möller A, Woodgate R, Lee C, Melling H, Karcher M (2011) Arctic oceanic gateways synthesis. Oceanogr 24:82-99, http://dxdoiorg/105670/oceanog201159

Carlson AE, LeGrande AN, Oppo DW, Came RE, Schmidt GA, Anslow FS, Licciardi JM, Obbink EA (2008) Rapid early Holocene deglaciation of the Laurentide ice sheet. Nature Geo 1:620-624

Carmack EC (2000) The Arctic Ocean's fresh-water budget: sources storage and export. In: EL Lewis P Lemke TD Prowse P Wadhams (eds) The freshwater budget of the Arctic Ocean. NATO/WCRP/AOSB, Kluwer Academic Publications, Amsterdam. Proc WCRP/AOSB/NATO Adv Res Wksp, Tallinn Estonia, April 1998, pp. 91-126.

Carmack EC, Macdonald RW, Perkin RG, McLaughlin FA, Pearson RJ (1995) Evidence for warming of Atlantic water in the southern Canadian Basin of the Arctic Ocean: Results from the Larsen-93 expedition. Geophys Res Lett 22:1061-1064 
Carmack EC, McLaughlin FA, Vagle S, Melling H, Williams WJ (2010) Structures and property distributions in the three oceans surrounding Canada in 2007: a basis for a long-term ocean climate monitoring strategy. Atmos Oc 48:211-224. doi:10.3137/OC324.2010

Coachman LK, Barnes CA (1961) The contribution of Bering Sea water to the Arctic Ocean. Arctic 14:147-161

Comiso JC, Parkinson CL, Gersten R, Stock L (2008) Accelerated decline in the Arctic sea ice cover. Geophys Res Lett 35:L01703. doi:101029/2007GL031972

Conkright ME, Antonov JL, Baranova O, Boyer TP, Garcia HE, Gelfeld R, Johnson D, Locarnini RA, Murphy PP, O’Brien TD, Smolyar I, Stephens C (2002) World Ocean Data Base 2001. In: S Levitus (ed) NOAA Atlas v 1. NESDIS 42. US Government Printing Office, Washington DC, pp. 167

Cooper LW, Whitledge TE, Grebmeier JM, Weingartner T (1997) The nutrient salinity and stable oxygen isotope composition of Bering and Chukchi Seas waters in and near the Bering Strait. J Geophys Res 102:12563-12573. doi:10.1029/97jc00015

Cooper LW, Cota GF, Pomeroy LR, Grebmeier JM, Whitledge EE (1999) Modification of NO, PO, and NO/ PO during flow across the Bering and Chukchi shelves: implications for use as Arctic water mass tracers. J Geophys Res 104:7827-7836

Darby DA, Bischof JF (2004) A Holocene record of changing Arctic Ocean ice drift analogous to the effects of the Arctic Oscillation. Paleoceanogr 19:PA1027. doi:101029/2003PA000961

Dmitrenko IA, Kirillov SA, Tremblay LB, Bauch D, Hölemann JA, Krumpen T, Kassens H, Wegner C, Heinemann G, Schröder D (2010) Impact of the Arctic Ocean Atlantic water layer on Siberian shelf hydrography. J Geophys Res 115:C08010. doi:10.1029/2009JC006020

Drinkwater KF, Harding GC (2001) Effects of the Hudson Strait outflow on the biology of the Labrador Shelf. Can J Fish Aquat Sci 58:171-184. doi:10.1139/cjfas-58-1-171

Dumas JA, Melling H, Flato GM (2007) Late-summer pack ice in the Canadian Archipelago: thickness observations from a ship in transit. Atmos-Oc 45:57-70

Dyck S, Tremblay BL, de Vernal A (2010) Arctic sea-ice cover from the early Holocene: the role of atmospheric circulation patterns. Quatern Sci Rev 29:3457-3467

Dyke AS, Hooper J, Savelle JM (1996) A history of sea ice in the Canadian Arctic Archipelago based on postglacial remains of the bowhead whale (Balaena mysticetus). Arctic 49:235-255

Edmonds HN, Moran SB, Hoff JA, Smith JN, Edwards RL (1998) Protactinium-231 and Thorium-230 Abundances and high scavenging rates in the western Arctic Ocean. Science 280:405-407. doi:10.1126/science.280.5362.405

England J, Atkinson N, Bednarski J, Dyke AS, Hodgsonn DA, Cofaigh CÓ (2006) The Innuitian Ice Sheet: configuration dynamics and chronology. Quatern Sci Rev 25:689-703

Fortin M-C, Gajewski K (2010) Postglacial environmental history of western Victoria Island Canadian Arctic. Quatern Sci Rev 29:2099-2110

Goldstein SL, Hemming SR (2004) Long-lived isotopic tracers in oceanography paleoceanography and icesheet dynamics. In: HD Holland KK Turekian (eds) Treatise on Geochemistry. Elsevier BV, Netherlands, 6, pp. 453-489

Guay CK, Falkner KK (1998) A survey of dissolved barium in the estuaries of major Arctic rivers and adjacent seas. Cont Shelf Res 18:859-882. doi:10.1016/S0278-4343

Hannah CG, Dupont F, Dunphy M (2009) Polynyas and tidal currents in the Canadian Arctic Archipelago. Arctic 62:83-95

Hill V, Cota G, Stockwell D (2005) Spring and summer phytoplankton communities in the Chukchi and Eastern Beaufort Seas. Deep-Sea Res II 52:3369-3385

Jones EP, Swift JH, Anderson LG, Lipizer M, Civitarese G, Falkner KK, Kattner G, McLaughlin FA (2003) Tracing Pacific water in the North Atlantic Ocean. J Geophys Res 108. doi:10.1029/2001jc001141

Kaufman DS, Schneider DP, McKay NP, Ammann CA, Bradley RS, Briffa KR, Miller GH, Otto-Bliesner BL, Overpeck JT, Vinther BM (2009) Recent warming reverses long-term Arctic cooling. Science 325:12361239

Kwok R, Cunningham GF, Wensnahan M, Rigor I, Zwally HJ, Yi D (2009) Thinning and volume loss of the Arctic Ocean sea ice cover: 2003-2008. J Geophys Res - Oceans 114:CO7005. doi:10.1029/ 2009JC005312

Leblond PH (1980) On the surface circulation in some channels of the Canadian Arctic Archipelago. Arctic 33:189-197

Ledu D, Rochon A, de Vernal A, Barletta F, St-Onge G (2010) Holocene sea-ice history and climate variability along the main axis of the Northwest Passage Canadian Arctic. Paleoceanogr 25:2213. doi:101029/ 2009PA001817

Lewis EL, Jone EP, Lemke P, Prowsw TD, Wadhams P (2000) The freshwater budget of the Arctic Ocean. NATO/WCRP/AOSB, Kluwer Academic Publications, Amsterdam. Proc WCRP/AOSB/NATO Adv Res Wksp, Tallinn Estonia, April 1998, pp. 479-502 
Lobb J, Carmack EC, Ingram RG, Weaver AJ (2003) Structure and mixing across an Arctic/Atlantic front in northern Baffin Bay. Geophys Res Lett 30:1833. doi:10.1029/2003GL017755

Macdonald RW, Gobeil C (2011) Manganese sources and sinks in the Arctic Ocean with reference to periodic enrichments in basin sediments. Aquat Geochem. doi:10.1007/s10498-011-9149-9

McBean GA, Alekseev G, Chen D, Forland E, Fyfe J, Groisman PY, King R, Melling H, Vose R, Whitfield PH (2005) Arctic climate: past and present. In: Arctic climate impact assessment $\mathrm{Ch} 2$, Cambridge University Press, pp. 1042

McKay JL, de Vernal A, Hillaire-Marcel C, Not C, Polyak L, Darby DA (2008) Holocene fluctuations in Arctic sea ice cover: dinocyst-based reconstructions for the eastern Chukchi Sea. Can J Earth Sci 45:1377-1397

McLaughlin FA, Carmack EC, Macdonald RW, Bishop JKB (1996) Physical and geochemical properties across the Atlantic/Pacific water mass front in the southern Canadian Basin. J Geophys Res 101:11831197

McLaughlin FA, Carmack EC, Macdonald RW, Weaver AJ, Smith J (2002) The Canada Basin 1989-1995: upstream events and far-field effects of the Barents Sea. J Geophys Res 107. doi:10.1029/2001JC000904

McLaughlin FA, Carmack EC, Proshutinsky A, Krishfield RA, Guay C, Yamamoto-Kawai M, Jackson JM, Williams B (2011) The rapid response of the Canada Basin to climate forcing: from bellwether to alarm bells. Oceanogr 24:146-159, http://dxdoiorg/105670/oceanog201166

Measures C (1999) The role of entrained sediments in sea ice in the distribution of aluminium and iron in the surface waters of the Arctic Ocean. Mar Chem 68:59-70

Melling H (2000) Exchanges of freshwater through the shallow straits of the North American Arctic. The Freshwater Budget of the Arctic Ocean. NATO/WCRP/AOSB, Kluwer Academic Publications, Amsterdam. 479-502. Proceedings of a WCRP/AOSB/NATO Advanced Research Workshop, Tallinn, Estonia, April 1998

Melling H (2002) Sea ice of the northern Canadian Arctic Archipelago. J Geophys Res 107:3181. doi:10.1029/2001JC001102,21 pp

Melling H, Lake RA, Topham DR, Fissel DB (1984) Oceanic thermal structure in the western Canadian Arctic. Cont Shelf Res 3:233-258

Melling H, Moore RM (1995) Modification of halocline source waters during freezing on the Beaufort Sea shelf: evidence from oxygen isotopes and dissolved nutrients. Cont Shelf Res 15:89-113

Melling H, Gratton Y, Ingram RG (2001) Ocean circulation within the North Water Polynya of Baffin Bay. Atmos-Oc 39:301-325

Melling H, Riedel DA, Gedalof Z (2005) Trends in the draft and extent of seasonal pack ice Canadian Beaufort Sea. Geophys Res Lett 32:L24501. doi:101029/2005GL024483

Melling H, Agnew TA, Falkner KK, Greenberg DA, Lee CM, Münchow A, Petrie B, Prinsenberg SJ, Samelson RM, Woodgate RA (2008) Fresh-water fluxes via Pacific and Arctic outflows across the Canadian polar shelf. In: RR Dickson et al. (eds) Arctic-SubArctic Ocean Fluxes: defining the role of the northern seas in climate. Springer Science + Business Media BV. PO Box 17, 3300 AA Dordrecht, The Netherlands, pp. 193-247

Mulligan RP, Perrie W, Solomon S (2010) Dynamics of the Mackenzie River plume on the inner Beaufort shelf during an open water period in summer. Estuar Coast Shelf Sci 89:214-220

Münchow A, Melling H, Falkner KK (2006) An observational estimate of volume and freshwater flux leaving the Arctic Ocean through Nares Strait. J Phys Oceanogr 36:2025-2041

Münchow A, Falkner KK, Melling H (2007) Spatial continuity of measured seawater and tracer fluxes through Nares Strait, a dynamically wide channel within the Canadian Archipelago. J Mar Res 65:759788

Polyakov A IV, Beszczynska ECC, Dmitrenko IA, Fahrbach E, Frolov IE, Gerdes R, Hansen E, Holfort J, Ivanov VV et al (2005) One more step toward a warmer Arctic. Geophys Res Lett 32:L17605. doi:10.1029/2005GL023740

Polyakov IV, Johnson MA (2006) Arctic decadal and inter-decadal variability. Geophys Res Lett 27:40974100

Polyakov VA IV, Alexeev GIB, Dmitrenko IA, Ivanov VV, Kirillov SA, Korablev AA, Steele M, Timokhov LA, Yashayaev I (2008) Arctic Ocean freshwater changes over the past 100 years and their causes. J Clim 21:364-384. doi:10.1175/2007JCLI1748.1

Porcelli D, Andersson S, Baskaranc M, Frankd M, Björk G, Semiletov I (2009) The distribution of neodymium isotopes in Arctic Ocean basins. Geochim Cosmochim Acta 73:2645-2659. doi:10.1016/ j.gca.2008.11.046

Prinsenberg SJ, Hamilton J, Peterson I, Pettipas R (2009) Observing and interpreting the seasonal variability of the oceanographic fluxes passing through Lancaster Sound of the Canadian Arctic Archipelago. In: Nihoul J, Kostianoy A (eds) Influence of climate change on the changing Arctic and Sub-Arctic 
Conditions. NATO Science for Peace and Security Series C: Environmental Security. Springer-Verlag, Dordrecht, The Netherlands, pp. 119-137 http://dxdoiorg/101007/978-1-4020-9460-6_10

Proshutinsky A, Krishfield R, Timmermans ML, Toole J, Carmack EC, McLaughlin FA, Williams WJ, Zimmermann S, Itoh M, Shimada K (2009) Beaufort Gyre freshwater reservoir: state and variability from observations. J Geophys Res 114:C00A10. doi:101029/2008JC005104

Rabe B, Muenchow A, Johnson H, Melling H (2010) Nares Strait hydrography and salinity field from a threeyear moored array. J Geophys Res 115:C07010. doi:101029/2009JC005966

Rabe B, Karcher M, Schauer U, Toole JM, Krishfield RA, Pisarev S, Kauker F, Gerdes R, Kikuchi T (2011) An assessment of Arctic Ocean freshwater content changes from the 1990s to the 2006-2008 period. Deep Sea Res I 58:173-185. doi:10.1016/j.dsr.2010.12.002

Rigor IG, Wallace JM, Colony RL (2002) On the response of sea ice to the Arctic Oscillation. J Clim $15: 2546-2663$

Rimbu N, Lohmann G, Kim J-H, Arz HW, Schneider R (2003) Arctic/North Atlantic oscillation signature in Holocene sea surface temperature trends as obtained from alkenone data. Geophys Res Lett 30:1280. doi:101029/2002GL016570

Royer TC (1998) Coastal Processes in the Northern North Pacific Coastal Segment. Wiley, pp. 395414

Rudels B, Anderson LG, Jones EP (1996) Formation and evolution of the surface mixed layer and halocline of the Arctic Ocean. J Geophys Res 101:8807-8821

Samelson RM, Agnew T, Melling H, Münchow A (2006) Evidence for atmospheric control of sea-ice motion through Nares Strait. Geophys Res Lett 33:L02506. doi:101029/2005GL025016

Samelson RM, Barbour PL (2008) Low-level jets orographic effects and extreme events in Nares Strait: a model-based mesoscale climatology. Mon Weath Rev 136:4746-4759. doi:101175/2007MWR23261

Schauer U, Beszczynska-Möller A, Walczowski W, Fahrbach E, Piechura J, Hansen E (2008) Variation of measured heat flow through the Fram Strait between 1997and 2006. In: Dickson RR, Meincke J, Rhines P (eds) Arctic-SubArctic ocean fluxes. Springer, Dordrecht, pp 65-85

Shimada K, McLaughlin FA, Carmack EC, Proshutinsky A, Nishino S, Itoh M (2004) Penetration of the 1990s warm temperature anomaly of Atlantic Water in the Canada Basin. Geophys Res Lett 31. doi:10.1029/2004GL020860

Tang CCL, Ross CK, Yao T, Petrie B, DeTracey BM, Dunlap E (2004) The circulation, water masses and seaice of Baffin Bay. Prog Oceanogr 63:183-208. doi:10.1016/j.pocean.2004.09.005

Tivy A, Howell SEL, Alt B, McCourt S, Chagnon R, Crocker G, Carrieres T, Yackel JJ (2011) Trends and variability in summer sea ice cover in the Canadian Arctic based on the Canadian Ice Service Digital Archive 1960-2008 and 1968-2008. J Geophys Res 116:C03007. doi:101029/2009JC005855

Tovar-Sánchez A, Duarte CM, Alonso JC, Lacorte S, Tauler R, Galbán-Malagón C (2010) Impacts of metals and nutrients released from melting multiyear Arctic sea ice. J Geophys Res 115:C07003. doi:10.1029/ 2009JC005685

Tremblay JE, Michel C, Hobson KA, Gosselin M, Price NM (2006) Bloom dynamics in early opening waters of the Arctic Ocean. Limnol Oceanogr 51:900-912

Vellinga M, Dickson B, Curry R (2008) The changing view on how freshwater impacts the Atlantic Meridional Overturning Circulation. In: Dickson RR, Meincke J, Rhines P (eds) Arctic-SubArctic ocean fluxes. Springer, Dordrecht, pp 289-314

Wang Q, Myers PG, Hu X, Bush ABG (2012) Flow constraint on pathways through the Canadian Arctic Archipelago. J Geophys Res 116:C03007. doi:1029/2009JC005855

Weingartner T, Aagaard K, Woodgate R, Danielson S, Sasaki Y, Cavalieri D (2005a) Circulation on the north central Chukchi Sea shelf. Deep Sea Res II 52:3150-3174. doi:10.1016/j.dsr2.2005.10.015

Weingartner TJ, Danielson SL, Royer TC (2005b) Freshwater variability and predictability in the Alaska Coastal Current. Deep-Sea Res II 52:169-191. doi:10.1016/j.dsr2.2004.09.030

Woodgate RA, Aagaard K, Weingartner TJ (2006) Inter-annual changes in the Bering Strait fluxes of volume heat and freshwater between 1991 and 2004. Geophys Res Lett 33:L15609. doi:10.1029/2006GL026931

Woodgate RA, Weingartner T, Lindsay R (2010) The 2007 Bering Strait oceanic heat flux and anomalous Arctic sea-ice retreat. Geophys Res Lett 37:L01602. doi:10.1029/2009GL041621

Xu F, Perrie W, Solomon S (2011) Shallow water dissipation processes for wind-waves off the Mackenzie Delta. Atmos-Oc, in review

Yamamoto-Kawai M, McLaughlin FA, Carmack EC, Nishino S, Shimada K (2009) Aragonite undersaturation in the Arctic Ocean: effects of ocean acidification and sea ice melt. Science 236:10981100

Yamamoto-Kawai M, Carmack EC, McLaughlin FA (2006) Nitrogen balance and Arctic through-flow. Nature 443:43. doi:10.1038/443043a 
Yashayaev I, Holliday NP, Bersch M, van Aken HM (2008) The history of the Labrador Sea Water: production, spreading, transformation and loss. In: Dickson RR, Meincke J, Rhines P (eds) ArcticSubArctic Ocean Fluxes: defining the role of the Northern Seas in climate. Springer, Netherlands Dordrecht, pp 569-612

Zweng M, Münchow A (2006) Warming and freshening of Baffin Bay 1916-2003. J Geophys Res 111: C07016. doi:101029/2005JC003093 